\title{
Front Matter: Volume 7572
}

, "Front Matter: Volume 7572," Proc. SPIE 7572, Optical Diagnostics and Sensing X: Toward Point-of-Care Diagnostics, 757201 (25 March 2010); doi: 10.1117/12.855919

SPIE. Event: SPIE BiOS, 2010, San Francisco, California, United States 
PROGRESS IN BIOMEDICAL OPTICS AND IMAGING

Vol. 11 , No. 25

\section{Optical Diagnostics and Sensing $X$ : Toward Point-of-Care Diagnostics}

Gerard L. Coté

Editor

25-26 January 2010

San Francisco, California, United States

Sponsored and Published by

SPIE

Volume 7572

Proceedings of SPIE, 1605-7422, v. 7572

SPIE is an international society advancing an interdisciplinary approach to the science and application of light. 
The papers included in this volume were part of the technical conference cited on the cover and title page. Papers were selected and subject to review by the editors and conference program committee. Some conference presentations may not be available for publication. The papers published in these proceedings reflect the work and thoughts of the authors and are published herein as submitted. The publisher is not responsible for the validity of the information or for any outcomes resulting from reliance thereon.

Please use the following format to cite material from this book:

Author(s), "Title of Paper," in Optical Diagnostics and Sensing X: Toward Point-of-Care Diagnostics, edited by Gerard L. Coté, Proceedings of SPIE Vol. 7572 (SPIE, Bellingham, WA, 2010) Article CID Number.

ISSN 1605-7422

ISBN 9780819479686

Published by

SPIE

P.O. Box 10, Bellingham, Washington 98227-0010 USA

Telephone +1 3606763290 (Pacific Time) · Fax +1 3606471445

SPIE.org

Copyright (C) 2010, Society of Photo-Optical Instrumentation Engineers.

Copying of material in this book for internal or personal use, or for the internal or personal use of specific clients, beyond the fair use provisions granted by the U.S. Copyright Law is authorized by SPIE subject to payment of copying fees. The Transactional Reporting Service base fee for this volume is $\$ 18.00$ per article (or portion thereof), which should be paid directly to the Copyright Clearance Center (CCC), 222 Rosewood Drive, Danvers, MA 01923. Payment may also be made electronically through CCC Online at copyright.com. Other copying for republication, resale, advertising or promotion, or any form of systematic or multiple reproduction of any material in this book is prohibited except with permission in writing from the publisher. The CCC fee code is 1605 $7422 / 10 / \$ 18.00$.

Printed in the United States of America.

Publication of record for individual papers is online in the SPIE Digital Library.

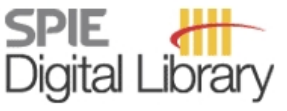

SPIEDigitallibrary.org

Paper Numbering: Proceedings of SPIE follow an e-First publication model, with papers published first online and then in print and on CD-ROM. Papers are published as they are submitted and meet publication criteria. A unique, consistent, permanent citation identifier (CID) number is assigned to each article at the time of the first publication. Utilization of CIDs allows articles to be fully citable as soon they are published online, and connects the same identifier to all online, print, and electronic versions of the publication. SPIE uses a six-digit CID article numbering system in which:

- The first four digits correspond to the SPIE volume number.

- The last two digits indicate publication order within the volume using a Base 36 numbering system employing both numerals and letters. These two-number sets start with 00, 01, 02, 03, 04, $05,06,07,08,09,0 A, 0 B \ldots 0 Z$, followed by 10-1Z, 20-2Z, etc.

The CID number appears on each page of the manuscript. The complete citation is used on the first page, and an abbreviated version on subsequent pages. Numbers in the index correspond to the last two digits of the six-digit CID number. 


\section{Contents}

vii Conference Committee

\section{SESSION 1 OPTICAL GLUCOSE MONITORING APPROACHES}

757202 Development of a real-time closed-loop dual-wavelength optical polarimeter for glucose monitoring [7572-01]

B. H. Malik, G. L. Coté, Texas A\&M Univ. (United States)

757203 Multivariate image processing technique for noninvasive glucose sensing [7572-02] A. J. Webb, B. D. Cameron, The Univ. of Toledo (United States)

$757204 \quad$ New scheme for polarimetric glucose sensing without polarizers [7572-03]

A. M. Winkler, G. T. Bonnema, College of Optical Sciences, The Univ. of Arizona (United States); J. K. Barton, The Univ. of Arizona (United States)

757205 Dynamic testing and in-vivo evaluation of dermally implantable luminescent microparticle glucose sensors [7572-04]

R. Long, B. Collier, J. Roberts, M. McShane, Texas A\&M Univ. (United States)

757206 Accurate glucose detection in a small etalon [7572-05]

J. Martini, S. Kuebler, M. Recht, F. Torres, J. Roe, P. Kiesel, R. Bruce, Palo Alto Research Ctr. (United States)

757207 Challenge for spectroscopic tomography of biomembrane using imaging type twodimensional Fourier spectroscopy [7572-06]

W. Qi, I. Ishimaru, Kagawa Univ. (Japan)

\section{SESSION 2 OPTICAL BLOOD PERFUSION AND OXYGENATION MONITORING}

757209 Optical sensor technology for a noninvasive continuous monitoring of blood components [7572-08]

J. Kraitl, Univ. of Rostock (Germany); U. Timm, E. Lewis, Univ. of Limerick (Ireland); H. Ewald, Univ. of Rostock (Germany)

7572 OA Blood flow measurement in extracorporeal circulation using self-mixing laser diode [7572-09]

S. Cattini, Univ. degli Studi di Modena (Italy); M. Norgia, A. Pesatori, Politecnico di Milano

(Italy); L. Rovati, Univ. degli Studi di Modena (Italy)

\section{SESSION 3 OPTICAL POINT-OF-CARE SYSTEMS}

7572 OB Low-cost fluorescence microscopy for point-of-care cell imaging [7572-11]

M. J. Lochhead, J. Ives, M. Givens, M. Delaney, K. Moll, C. J. Myatt, Precision Photonics Corp. (United States) 
7572 OC Tumor specific lung cancer diagnostics with multiplexed FRET immunoassays [7572-12] D. Geißler, D. Hill, H.-G. Löhmannsröben, Univ. Potsdam (Germany); E. Thomas, A. Lavigne, B. Darbouret, E. Bois, Cezanne S.A.S. (France); L. J. Charbonnière, Lab. d'Ingénierie Moléculaire Analytique, CNRS, Univ. Louis Pasteur (France); R. F. Ziessel, Lab. de Chimie Organique et Spectroscopie Avancée, CNRS, Univ. Louis Pasteur (France); N. Hildebrandt, Fraunhofer-Institut für Angewandte Polymerforschung (Germany)

7572 OD Guided-mode resonance sensor system for early detection of ovarian cancer [7572-13] D. Wawro, Resonant Sensors Inc. (United States); P. Koulen, Univ. of Missouri (United States); Y. Ding, S. Zimmerman, Resonant Sensors Inc. (United States); R. Magnusson, Resonant Sensors Inc. (United States) and Univ. of Texas at Arlington (United States)

7572 OE Multi-wavelength spectroscopy of oriented erythrocytes [7572-14]

Y. M. Serebrennikova, L. H. Garcia-Rubio, College of Public Health, Univ. of South Florida (United States) and Claro Scientific LLC (United States); J. M. Smith, D. E. Huffman, Claro Scientific LLC (United States)

\section{POSTER SESSION}

7572 OF Evaluation of the cell depleted layer of blood flow in vitro using confocal microscopic PIV method [7572-15]

S. H. Lim, H. Lee, C. Y. Lee, C. W. Park, Kyungpook National Univ. (Korea, Republic of)

7572 OG Monte Carlo simulation of zinc protoporphyrin fluorescence in the retina [7572-16]

X. Chen, S. Lane, Univ. of California, Davis (United States)

$7572 \mathrm{OH} \quad$ Research on the spectroscopy of turbid media with optical-length resolved detection [7572-17]

Z. Du, C. Li, F. Chen, W. Chen, K. Xu, Tianjin Univ. (China)

7572 ol Feasibility of analyte prediction in phantoms using a theoretical model of near-infrared spectra [7572-18]

F. Zou, B. Peshlov, Univ. of Massachusetts Medical School (United States); R. Ross, College of the Holy Cross (United States); G. E. C. Ellerby, P. J. Scott, Y. Yang, B. R. Soller, Univ. of Massachusetts Medical School (United States)

7572 0J An integrated CMOS dual lock-in amplifier for optoelectronic antigens detection [7572-19] N.-P. Hong, D.-G. Kim, I.-I. Jung, H.-H. Son, T.-K. Chung, Y. Choi, Y.-W. Choi, Chung-Ang Univ. (Korea, Republic of)

7572 OK Fast imaging system and algorithm for monitoring microlymphatics [7572-20] T. Akl, E. Rahbar, Texas A\&M Univ. (United States); D. Zawieja, A. Gashev, Texas A\&M Univ. Health Science Ctr. (United States); J. Moore, G. Coté, Texas A\&M Univ. (United States)

$7572 \mathrm{OL}$ Oblique-incidence spatially resolved diffuse reflectance spectroscopic diagnosis of skin cancer [7572-21]

A. Garcia-Uribe, Washington Univ. in St. Louis (United States) and Texas A\&M Univ. (United States); J. Zou, T.-H. Chang, Texas A\&M Univ. (United States); M. Duvic, V. Prieto, The Univ. of Texas M. D. Anderson Cancer Ctr. (United States); L. V. Wang, Washington Univ. in St. Louis (United States) 
7572 OM Comparison of different kinds of skin using Raman spectroscopy [7572-22]

A. E. Villanueva-Luna, J. Castro-Ramos, S. Vazquez-Montiel, Instituto Nacional de Astrofísica, Óptica y Electrónica (Mexico); A. Flores Gil, Instituto Nacional de Astrofísica, Óptica y Electrónica (Mexico) and Univ. Autónoma del Carmen (Mexico); J. A. Delgado-Atencio, Instituto Nacional de Astrofísica, Óptica y Electrónica (Mexico)

7572 OP Adulteration detection in milk using infrared spectroscopy combined with two-dimensional correlation analysis [7572-26]

B. He, R. Liu, R. Yang, K. Xu, Tianjin Univ. (China)

Author Index 
Downloaded From: https://www.spiedigitallibrary.org/conference-proceedings-of-spie on 26 Apr 2023

Terms of Use: https://www.spiedigitallibrary.org/terms-of-use 


\title{
Conference Committee
}

\author{
Symposium Chairs \\ James G. Fujimoto, Massachusetts Institute of Technology (United \\ States) \\ R. Rox Anderson, Wellman Center for Photomedicine, Massachusetts \\ General Hospital (United States) and Harvard School of Medicine \\ (United States)
}

Program Track Chairs

Ammasi Periasamy, University of Virginia (United States)

Daniel L. Farkas, Cedars-Sinai Medical Center (United States)

Conference Chair

Gerard L. Coté, Texas A\&M University (United States)

Program Committee

Rafat R. Ansari, NASA Glenn Research Center (United States)

Werner Gellermann, The University of Utah (United States)

Yuri I. Gurfinkel, Central Clinical Hospital (Russian Federation)

Jürgen M. Lademann, Charité Universitätsmedizin Berlin (Germany)

Michael J. McShane, Texas A\&M University (United States)

Kenith E. Meissner, Texas A\&M University (United States)

Risto A. Myllylä, University of Oulu (Finland)

Gert E. Nilsson, University Hospital Linköping (Sweden)

Jeffery S. Reynolds, Bayer Healthcare (United States)

Wiendelt Steenbergen, Universiteit Twente (Netherlands)

Kexin Xu, Tianjin University (China)

Shaoqun Zeng, Britton Chance Center for Biomedical Photonics

(China)

Dmitry A. Zimnyakov, Saratov State University (Russian Federation)

Session Chairs

1 Optical Glucose Monitoring Approaches

Michael J. McShane, Texas A\&M University (United States)

2 Optical Blood Perfusion and Oxygenation Monitoring

Gerard L. Coté, Texas A\&M University (United States)

3 Optical Point-of-Care Systems

Gerard L. Coté, Texas A\&M University (United States) 
Downloaded From: https://www.spiedigitallibrary.org/conference-proceedings-of-spie on 26 Apr 2023

Terms of Use: https://www.spiedigitallibrary.org/terms-of-use 